\title{
Nuclear Factor $\kappa$ B Deficiency Is Associated with Auditory Nerve Degeneration and Increased Noise-Induced Hearing Loss
}

\author{
Hainan Lang, ${ }^{1}$ Bradley A. Schulte, ${ }^{1,2}$ Daohong Zhou, ${ }^{1}$ Nancy Smythe, ${ }^{2}$ Samuel S. Spicer, ${ }^{1}$ and Richard A. Schmiedt ${ }^{2}$ \\ ${ }^{1}$ Department of Pathology and Laboratory Medicine, Medical University of South Carolina, Charleston, South Carolina 29425, and 2 Department of \\ Otolaryngology, Head and Neck Surgery, Medical University of South Carolina, Charleston, South Carolina 29425
}

\begin{abstract}
Degeneration of the spiral ganglion neurons (SGNs) of the auditory nerve occurs with age and in response to acoustic injury. Histopathological observations suggest that the neural degeneration often begins with an excitotoxic process affecting the afferent dendrites under the inner hair cells (IHCs), however, little is known about the sequence of cellular or molecular events mediating this excitotoxicity. Nuclear factor $\kappa \mathrm{B}(\mathrm{NF} \kappa \mathrm{B})$ is a transcription factor involved in regulating inflammatory responses and apoptosis in many cell types. NF $\kappa \mathrm{B}$ is also associated with intracellular calcium regulation, an important factor in neuronal excitotoxicity. Here, we provide evidence that $\mathrm{NF} \kappa \mathrm{B}$ can play a central role in the degeneration of SGNs. Mice lacking the p50 subunit of $\mathrm{NF} \kappa \mathrm{B}$ ( $\mathrm{p}_{50}^{-l-}$ mice) showed an accelerated hearing loss with age that was highly associated with an exacerbated excitotoxic-like damage in afferent dendrites under IHCs and an accelerated loss of SGNs. Also, as evidenced by immunostaining intensity, calcium-buffering proteins were significantly elevated in SGNs of the $\mathrm{p}^{-1-}$ mice. Finally, the knock-out mice exhibited an increased sensitivity to low-level noise exposure. The accelerated hearing loss and neural degeneration with age in the $\mathrm{p}^{-1-}$ mice occurred in the absence of concomitant hair cell loss and decline of the endocochlear potential. These results indicate that $\mathrm{NF} \kappa \mathrm{B}$ activity plays an important role in protecting the primary auditory neurons from excitotoxic damage and age-related degeneration. A possible mechanism underlying this protection is that the NF $\kappa \mathrm{B}$ activity may help to maintain calcium homeostasis in SGNs.
\end{abstract}

Key words: hearing loss; spiral ganglion neuron; $\mathrm{NF} \kappa \mathrm{B}$; noise; excitotoxicity; cochlea

\section{Introduction}

Spiral ganglion neurons (SGNs) are the primary carrier of auditory information from the sensory cells of the cochlea to the CNS. Degeneration of SGNs occurs with age and cochlear injuries resulting from noise, ototoxic drugs, and genetic mutations (Kiang et al., 1976; Keithley and Feldman, 1979; Leak and Hradek, 1988; White et al., 2000). The degeneration can be a primary event or occur secondarily as a result of hair cell loss. The process of SGN degeneration appears to involve apoptosis (Dodson, 1997). In vitro studies have shown that the degeneration of SGNs after loss of hair cells involves at least three mechanisms including (1) the cyclic AMP-dependent protein kinase and $\mathrm{Ca}^{2+} /$ calmodulindependent protein kinase II and IV systems, (2) pathways involving protein kinase $\mathrm{C}$ activation, $\mathrm{Ca}^{2+}$ signaling, and mitogenactivated protein kinases, and (3) the c-Jun N-terminal kinase cell-death pathway (Hanson et al., 1998; Green, 2000; Zha et al., 2001; Bodmer et al., 2002; Bok et al., 2003; Hansen et al., 2003;

Received Feb. 18, 2005; revised Jan. 24, 2006; accepted Feb. 16, 2006.

This work was supported by National Institutes of Health Grants R03DC-07506 (H.L.), R01AG-14748 (R.A.S.), R01DC-00713 (B.A.S.), and R01CA-78688 (D.Z.), MUSC Institution Research Funds (H.L.), and Grant C06 RR014516 from the Extramural Research Facilities Program of the National Center for Research Resources. We thank James Nicholson and Liya Liu for their technical assistance. We also thank three anonymous referees for suggested improvements.

Correspondence should be addressed to Hainan Lang, Department of Pathology and Laboratory Medicine, Medical University of South Carolina, 165 Ashley Avenue, P.0. Box 250908, Charleston, SC 29425. E-mail: langh@musc.edu.

DOI:10.1523/JNEUROSCI.2488-05.2006

Copyright $\odot 2006$ Society for Neuroscience $\quad$ 0270-6474/06/263541-10\$15.00/0
Lallemend et al., 2003). Recent studies have demonstrated that supporting cells in the inner hair cell (IHC) regions as well as neuregulin-erbB receptor signaling and the nicotinic acetylcholine receptor subunit $\beta 2$ are important for adult SGN survival (Stankovic et al., 2004; Bao et al., 2005; Sugawara et al., 2005). However, the intrinsic mechanisms mediating cell survival and cell death of auditory SGNs are still poorly defined.

The nuclear transcription factor $\kappa \mathrm{B}(\mathrm{NF} \kappa \mathrm{B})$ is known for its fundamental role in regulating inflammatory responses and apoptosis in response to insults in many cell types. The predominant complex of $\mathrm{NF} \kappa \mathrm{B}$ in most mammalian cells is p50/p65. Hippocampal pyramidal neurons in mice lacking the p50 subunit of $\mathrm{NF} \kappa \mathrm{B}\left(\mathrm{p} 50^{-/-}\right)$exhibit increased damage after exposures to excitotoxins (Yu et al., 1999; Kassed et al., 2002). However, little is known as to the role of $\mathrm{NF} \kappa \mathrm{B}$ in hearing loss and the degeneration of the auditory nerve. Here, we report that $\mathrm{p} 50^{-/-}$mice show an accelerated hearing loss and a progressive degeneration of SGNs with age.

$\mathrm{NF} \kappa \mathrm{B}$ activity may exact its influence on SGNs by upregulating gene products that regulate $\mathrm{Ca}^{2+}$ levels and modulate apoptosis (Guo et al., 1998; Camandola et al., 2005). The disturbance of $\mathrm{Ca}^{2+}$ homeostasis is a key element associated with excitotoxicity and neuronal degeneration (Mattson and Chan, 2001; Arundine and Tymianski, 2003; Mattson, 2003). Previous studies have shown that noise-induced hearing loss may be caused, in part, by excitotoxicity of SGNs. The excitotoxic damage to SGN is suggested by massive swelling of afferent dendrites under IHCs 
(Liberman and Mulroy, 1982; Robertson, 1983; Puel et al., 1998; Le Prell et al., 2004). To further test the hypothesis that NF $\kappa \mathrm{B}$ activity plays an important role in maintaining $\mathrm{Ca}^{2+}$ homeostasis and protecting SGNs from excitotoxic injury, we examined the expression of calcium-buffering proteins and the profile of afferent dendrites under IHCs in wild-type (WT) and $\mathrm{p}^{-0^{-1}}$ mice. In addition, we examined whether NF $\kappa \mathrm{B}$ activity effects cochlear susceptibility to noise-induced hearing loss by exposing the WT

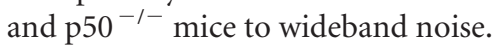

\section{Materials and Methods}

Animals. The gene-targeting strategy used to generate lines of mice lacking p50 has been described previously (Sha et al., 1995). B6,129PF2 (p50 WT) and B6,129P2-Nfkb1 (p50 knock-out or $\mathrm{p}^{-/-}$) mice were bred and housed in an Association for Assessment and Accreditation of Laboratory Animal Care-certified animal facility at the Medical University of South Carolina. The homozygous breeding pairs of WT and $\mathrm{p} 50^{-1-}$ mice were obtained from The Jackson Laboratory (Bar Harbor, ME). Genotyping was performed by PCR of DNA extracted from tail biopsies, as described previously (Sha et al., 1995). All mice received food and water ad libitum and were maintained on a $12 \mathrm{~h}$ light/dark cycle. One-, 3-, and 8-month-old mice were used in this study.

Animals were anesthetized with ketamine (100 mg/kg, i.p.) and xylazine $\left(20 \mathrm{mg} / \mathrm{kg}\right.$, i.p.). Body temperature was maintained at $37^{\circ} \mathrm{C}$ by using a heating pad throughout the experiment. Animals were tracheotomized and placed in a head holder in a heated sound- and vibration-isolated room. The pinna and ear canal were surgically removed, and the round window was carefully exposed via a small hole in the bulla. All experimental protocols were approved by the local Institutional Animal Care and Use Committee and met National Institutes of Health guidelines for animal care and use.

Noise exposure. The wideband noise was generated and digitally filtered in the frequency domain with TDT (Alachua, FL) modules and amplified. The sound was delivered with a Beyer DT48 drive (Beyerdynamic, Farmingdale, NY) and monitored with a probe-tube microphone (B\&K 4134; Bruel and Kjaer, Norcross, GA). Each anesthetized animal was exposed to a low-level wideband noise at $70 \mathrm{~dB}$ sound pressure level (SPL) for $2 \mathrm{~h}$ with one animal exposed at a time.

Physiological procedures. The procedures for recording the distortion production otoacoustic emissions (DPOAEs), compound action potential (CAP) response and endocochlear potential (EP) in the mouse were similar to those described previously, except that the DPOAEs here were obtained from unopened bullae (Lang et al., 2002, 2005). Physiological data were obtained from right ears. The animal was anesthetized as described above and fitted to a head holder in a sound- and vibrationisolated booth.

DPOAEs were measured with an Ariel board (Ariel, Cranbury, NJ) and CUBeDISP software (Etymotic Research, Elk Grove Village, IL) using a B\&K 4134 microphone, frequency equalizer, and probe tube. DPOAEs were obtained from unopened bulla after removing the pinna and underlying tissue. The intensity levels of both primaries were fixed at $70 \mathrm{~dB}$ SPL. The acoustic assembly, comprising a probe-tube microphone (B\&K 4134) and driver (Beyer DT48) was sealed to the ear canal with closed-cell foam. Primary tones were swept from $f_{2}=4-20 \mathrm{kHz}$ with an $f_{2} / f_{1}$ ratio of 1.2 and a resolution of 10 points per octave.

The silver-wire CAP electrode was placed inside the round-window niche and referenced to the neck musculature. The tone pips were generated in the frequency domain by TDT equipment and software. CAP thresholds were obtained visually with an oscilloscope at half-octave frequencies from $0.5-20 \mathrm{kHz}$ with tone pips of $1.8 \mathrm{~ms}$ total duration with $\cos ^{2}$ rise/fall times of $0.55 \mathrm{~ms}$. CAP input/output (I/O) functions in each ear were obtained at 2, 4, 8, and $16 \mathrm{kHz}$ at eight levels from 20 to $90 \mathrm{~dB}$ SPL by computer-averaging 24 epochs at each combination of level and frequency.

EPs were recorded in the basal turn of the cochlea. The EP was measured with a micropipette filled with $0.2 \mathrm{M} \mathrm{KCl} \mathrm{yielding} \mathrm{an} \mathrm{impedance} \mathrm{of}$ $\sim 20-30 \mathrm{M} \Omega$. The output of the micropipette was led to an electrometer (FD 223; World Precision Instruments, Sarasota, FL) for direct recording
Table 1. Swelling of auditory dendrites below the basal IHCs in WT and p50 ${ }^{-1-}$ mice

\begin{tabular}{llcc}
\hline Age & WT & $\mathrm{p} 50^{-/-}$ & $p$ values \\
\hline 1 month & $0.96 \pm 0.48(n=5)$ & $6.67 \pm 1.53(n=3)$ & 0.017 \\
3 months & $2.75 \pm 1.5(n=4)$ & $9 \pm 2.7(n=3)$ & 0.011
\end{tabular}

The sections were taken from the basal turns of cochleas. The numbers of swollen dendrites per IHC region were counted. Six sections were obtained per animal with three to five animals per group. Data are expressed as mean \pm SEM per IHC region. $n$, Number of animals per group. One-way ANOVA was used to examine the significance of the difference in the numbers of swollen dendrite terminals between WT and $\mathrm{p50}^{-1-}$ mice.

of the potential. The micropipette was introduced into scala media via $40-60 \mu \mathrm{m}$ holes drilled through the otic capsule in the basal turn. EP was defined as the voltage difference between scala media and a pool of isotonic saline on the neck muscles.

Light microscopy and tissue preparation. After the physiological recording, the anesthetized mice were perfused via cardiac catheter with $5 \mathrm{ml}$ of normal saline containing $0.1 \%$ sodium nitrite followed by $20 \mathrm{ml}$ of fixative solution consisting of $10 \%$ formalin and $0.5 \%$ zinc dichromate in $0.9 \%$ saline with the $\mathrm{pH}$ adjusted to 5.0 just before use. The cochleas were then dissected and immersed in fixative for $45 \mathrm{~min}$. The cochleas used for calcium-buffering protein immunohistochemistry and SGN quantification were decalcified with EDTA, dehydrated, embedded in paraffin, and sectioned at $6 \mu \mathrm{m}$ thickness.

Immunohistochemistry. Deparaffinized and rehydrated sections were immersed in blocking solution for $20 \mathrm{~min}$ and then incubated overnight with a primary antibody diluted in $\mathrm{PBS}$ at $4^{\circ} \mathrm{C}$. The primary antibodies used in this study were against the following: neurofilament 200 (1:200; Sigma, St. Louis, MO), isozyme 3 of plasma membrane Ca-ATPase (PMCA3) (1:500; Affinity BioReagents, Golden, CO), neuronal calcium sensor 1 (NCS1) (1:100; Santa Cruz, CA), calbindin D28K (1:500; Chemicon, Temecula, CA), and synaptophysin (1:100; Novo Laboratories, Newcastle, UK). Secondary antibodies were biotinylated and binding was detected with HRP techniques visualized by labeling with fluorescein (FITC)-conjugated avidin D. Nuclei were counterstained with propidium iodide (PI). Sections were examined on a Zeiss (Jena, Germany) LSM5 Pascal confocal microscope with an argon and HeNe laser. FITC and PI signals were detected by excitation with the $488 \mathrm{~nm}$ and 543 $\mathrm{nm}$ lines, respectively. Images were scanned at scales of $0.29 \mu \mathrm{m}(x) \times$ $0.29 \mu \mathrm{m}(y)$ and a stack size of $146.2 \mu \mathrm{m}(x) \times 146.2 \mu \mathrm{m}(y)$ with a plan-Apochromat $63 \times / 1.4$ oil differential interference contrast objective (Carl Zeiss). The captured images were processed using Zeiss LSM Image Browser version 3,2,0,70 and Adobe (San Jose, CA) Photoshop CS.

For auditory nerve fiber counts, neurofilament 200-positive nerve fibers were examined in every fifth section of the osseous spiral lamina in the basal turn of 1-, 3-, and 8-month-old WT and knock-out mice. The number of nerve fibers passing through 10 habenular openings was counted for each selected section and the average number of fibers per habenula was calculated.

For spiral ganglion cell counts, ganglion cells were examined in every fifth section of Rosenthal's canal in the basal turns of 1-, 3-, and 8-month-old WT and knock-out mice, and at least three sections per animal were counted. The number of spiral ganglion cells over a crosssectional area of $146.2 \times 146.2 \mu \mathrm{m}$ was counted and the average cell density was calculated.

Comparisons of immunostaining of calcium-buffering protein in SGNs were made from the images with the same setup for the confocal image acquirements: the pinhole was $106 \mu \mathrm{m}$ and the wavelength at 488 and $543 \mathrm{~nm}$ was 2.0 and $80 \%$, respectively. Care was taken to restrict the sample to the same region of Rosenthal's canal in the basal turn. Eightmonth-old WT and 8-month-old p50 ${ }^{-1-}$ mice were examined. Each pair of WT and knock-out sections was prepared for immunostaining together. The investigator was blind with regard to the mouse strains. The pixel intensity of FITC in individual neurons with each antibody was evaluated by using the histogram function in Adobe Photoshop CS. The pixel intensity was measured in 10 neurons randomly selected within the observed field of $146.2 \times 146.2 \mu \mathrm{m}$ and averaged. Relative intensity was quantified by calculating the ratio of the average pixel intensity of the neuron to that of the background in the same field. Three animals per 
A

B
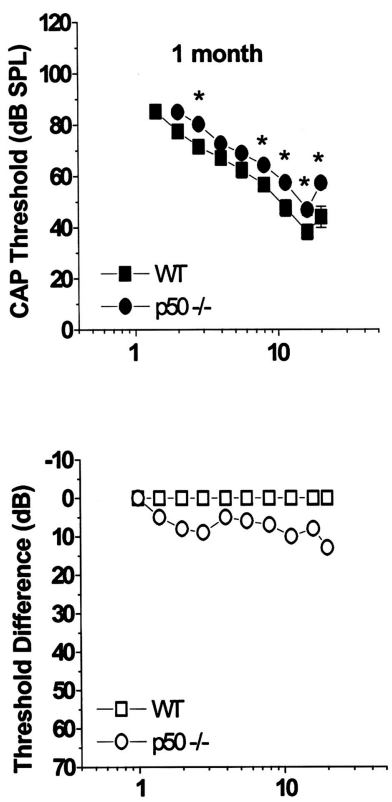

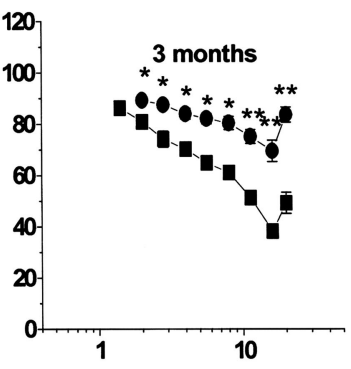

Frequency (kHz)

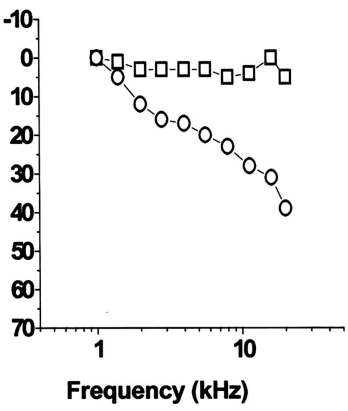

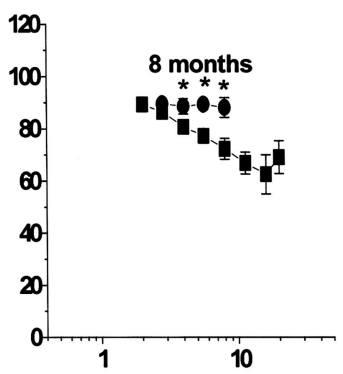

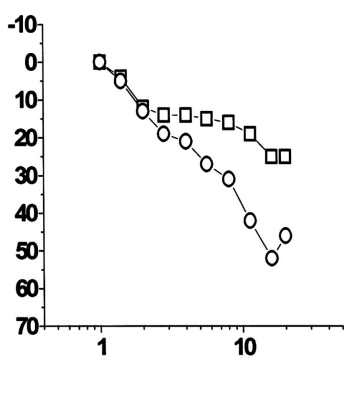

Figure 1. Age-related accelerated hearing loss in $\mathrm{p50}^{-1-}$ mice. Physiological measurements in $\mathrm{p} 50^{-1-}$ and WT mice in the three age groups are shown. $\boldsymbol{A}$, Mean CAP thresholds \pm SEM obtained from groups at 1,3 , and 8 months of age ( $n=9$ for each group). Asterisks indicate statistically significant differences at the indicated frequency (ANOVA, ${ }^{*} p<0.05 ;{ }^{* *} p<0.01$ ). At 1 month of age, CAP thresholds in the knock-outs were elevated by $6-10 \mathrm{~dB}$ relative to the wild-type group at all frequencies. At 3 months of age, thresholds in knock-outs were elevated by $30 \mathrm{~dB}$ at higher frequencies and by $20 \mathrm{~dB}$ at lower frequencies. By 8 months of age, most $\mathrm{p}^{-1-}$ mice no longer responded to auditory stimuli at the higher frequencies, whereas the WT mice retained CAP responses at most frequencies tested. $\boldsymbol{B}$, Difference in mean threshold shifts compared with 1-month-0ld WT mean thresholds.

group and three sections per animal were examined. From the mean pixel intensity of neurons obtained for each cochlea, we can calculate the average value for each group.

Hair-cell quantification. The procedures for counting hair cells on surface preparations of the basilar membrane have been described previously (Ding et al., 2001). The basilar membrane was carefully dissected from the fixed cochlea, stained with FITC-labeled phalloidin $(1 \mu \mathrm{g} / \mathrm{ml}$ in PBS) to label filamentous actin for $20 \mathrm{~min}$ and with PI ( $1 \mu \mathrm{g} / \mathrm{ml}$ in PBS) to label nuclei for $10 \mathrm{~min}$. Hair cells were identified by the presence of the actin-rich hair bundles, the actin belt that rings the apical surface of the cell and a healthy nucleus. Hair cell counts were made from four cochleas of 1-month-old WT mice, four cochleas of 1-month-old knock-out mice, six cochleas of 8-month-old WT mice, and six cochleas of 8-month-old knock-out mice. Separate outer hair cell (OHC) and IHC counts were made over $0.10-0.15 \mathrm{~mm}$ intervals of the organ of Corti beginning at the apex. All three rows of OHCs were included in OHC counts. Mean hair-cell densities were calculated by averaging cell density data over successive 20,30,30, and 20\% segments of the cochlea, referred to as apex, midapex, midbase, and base, respectively.

Transmission electron microscopy. The anesthetized animals were perfused via cardiac catheter first with $10 \mathrm{ml}$ of normal saline containing $0.1 \%$ sodium nitrite followed by $15 \mathrm{ml}$ of a mixture of $4 \%$ paraformaldehyde and $2 \%$ glutaraldehyde in $0.1 \mathrm{~m}$ phosphate buffer, $\mathrm{pH} 7.4$. After removing the stapes and opening the oval and round windows, $0.5 \mathrm{ml}$ of fixative was perfused gently into the scala vestibuli through the oval window. The inner ears were dissected free and immersed in fixative overnight at $4^{\circ} \mathrm{C}$. Decalcification was completed by immersion in $400 \mathrm{ml}$ of $120 \mathrm{~mm}$ solution of EDTA, pH 7.0, with gentle stirring at room temperature for 2-3 d with daily changes of the EDTA solution. The tissues were postfixed with $1 \%$ osmium tetroxide, $1.5 \%$ ferrocyanide for $2 \mathrm{~h}$ in the dark, dehydrated, and embedded in Epon LX 112 resin. Semithin sections, $\sim 1 \mu \mathrm{m}$ thick, were cut and stained with toluidine blue. Ultra- thin sections were stained with uranyl acetate and lead citrate and examined by electron microscopy.

To quantify the swollen dendritic terminals under each IHC in the basal turns of WT and p50 $0^{-1-}$ mice, we used the criteria for swollen dendritic terminals that have been described previously (Hakuba et al., 2000), where vacuole-like spaces replace the afferent terminals of the inner radial nerves. Five 1-monthold WT mice, three 1-month-old $\mathrm{p} 50^{-1-}$ mice, four 3-month-old WT mice, and three 3-month-old $\mathrm{p}^{-1-}$ mice were examined. At least six IHC regions from each animal in basal turn were examined and the average of the swollen dendritic terminals per IHC region was calculated (Table 1).

Data analysis. Mean CAP thresholds were compared by using a two-way ANOVA (SPSS, Chicago, IL), with genotype as a betweensubject variable and frequency as a repeated measure. Mean DPOAE amplitudes, EP values, the results of hair-cell and auditory nerve counts, and the pixel intensity of calciumbuffering proteins were compared by using one-way ANOVA with genotypes as a betweensubject variable. Differences between means were considered statistically significant when $p<0.05$.

\section{Results}

Accelerated hearing loss in $\mathrm{p} 50^{-1-}$ mice The original p50 mutation was made in the $129 /$ SvEv mouse strain and then backcrossed to C57BL/6J mice (Sha et al., 1995). Both the C57BL/6J and the 129/

SvEv strains have hearing losses that begin at high frequencies and progress with age (Willott, 1986; Q. Y. Zheng et al., 1999; White et al., 2000; Lang et al., 2002). CAP thresholds in the wild-type mice show large elevations at 8 months of age. However, CAP threshold shifts in $\mathrm{p} 50^{-1-}$ mice are accelerated with age compared with WT mice, as shown in Figure $1, A$ and $B$. At 1 month of age, CAP thresholds in the knock-outs were elevated by $6-20 \mathrm{~dB}$ SPL relative to the wildtype at almost all frequencies. At 3 months of age, CAP thresholds in $\mathrm{p}^{-1-}$ mice were increased by $\sim 20 \mathrm{~dB}$ SPL at low frequencies and by $\sim 30 \mathrm{~dB}$ at high frequencies compared with the WT. By 8

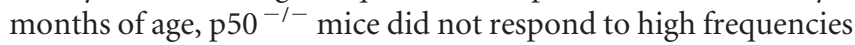
at $90 \mathrm{~dB}$ SPL, whereas the WT mice still had CAP responses at most frequencies tested.

Otoacoustic emissions allow testing of $\mathrm{OHC}$ function in vivo (Horner et al., 1985). DPOAEs were recorded from unopened bullae of groups of 3-month-old $\mathrm{p} 50^{-1-}$ and WT mice $(n=8$ for each group) (Fig. $2 A$ ). Primaries were presented at $70 \mathrm{~dB}$ SPL. In both genotypes, the detectable emissions were found at the higher end of the frequency range $(8-20 \mathrm{kHz})$. There was no significant loss of DPOAEs in knock-out mice compared with the WT mice (ANOVA, $p>0.05$ ).

Our previous study showed that there was no significant loss of $\mathrm{EP}$ in C57BL/6J mice up to at least 24 months of age (Lang et al., 2002). Similarly, there was no EP reduction in WT mice at 3 and 8 months of age compared with 1-month-old WT mice (ANOVA, $p>0.05$ ) (Fig. $2 B$ ). There was also no reduction of EP with age in $\mathrm{p}^{-1-}$ mice (ANOVA, $p>0.05$ ). At 1,3 , and 8 months of age, mean $\mathrm{EP}$ values of $\mathrm{p} 50^{-1-}$ mice were $110 \pm 4.2$, 

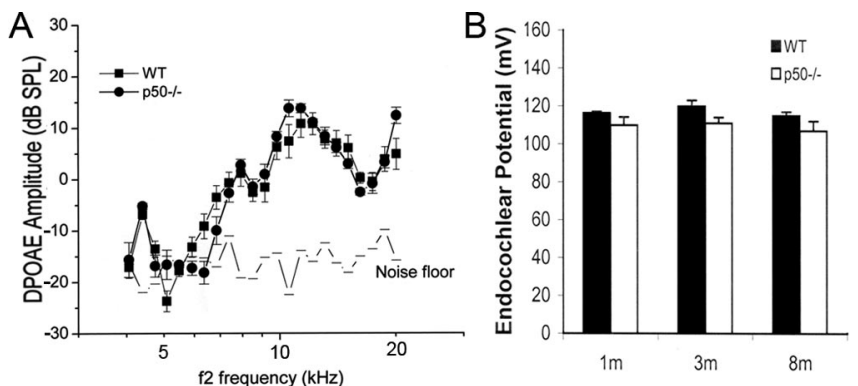

Figure 2. The deficiency in the $\mathrm{p} 50$ subunit of $\mathrm{NF} \kappa \mathrm{B}$ does not affect $\mathrm{OHC}$ and lateral wall function compared with WT mice. A, DPOAEs obtained with constant level ( $\mathrm{L} 1=\mathrm{L2}=70 \mathrm{~dB}$ SPL) primaries from eight WT and eight knock-out mice at 3 months of age. Error bars represent SEM. The differences of DPOAE amplitudes between WT and knock-out mice were not statistically significant (ANOVA, $p>0.05$ ). $\boldsymbol{B}$, Mean EP values obtained from basal turns from the same animals shown in Fig. 1. Data are expressed as mean \pm SEM ( $n=9$ for each group). No EP reduction with age was found in either the wild-type or the $\mathrm{p}^{-1-} 0^{-1}$ mice (ANOVA, $p>0.05$ ). EP differences between WT and knock-out mice were not statistically significant at ages of 1, 3, and 8 months, respectively (ANOVA, $p>0.05$ ).

$111 \pm 3.1$, and $107 \pm 5.1 \mathrm{mV}$, respectively. Mean EP values in WT mice were $116 \pm 1.1,120 \pm 3.1$, and $115 \pm 1.9 \mathrm{mV}$, respectively. There was no significant difference between knock-out and WT mice in any of three groups (ANOVA, $p>0.05$ ).

\section{Excitotoxic-like damage of afferent dendrites under IHC}

Synapses under IHCs in the mammalian cochlea are of two types: afferent and efferent endings (Rasmussen, 1953; Engström, 1958). The structural features of afferent and efferent endings make them easily distinguished by transmission electron microscopy (Fig. 3A). The afferent synapses are characterized by a thick postsynaptic membrane density and contain filamentous and granular material. Efferent synaptic specializations are characterized by accumulations of many synaptic vesicles and electrondense conical spicules on the membrane. It is generally accepted that the efferent fibers associated with IHCs often synapse with the radial afferent dendrites beneath the IHC and do not directly contact the IHC body. However, some studies have also demonstrated that both afferent and efferent fibers contact directly with IHCs in the monkey and mouse cochlea (Kimura, 1984; Sobkowicz et al., 2004).

Damage to radial afferent dendrites beneath IHCs occurs after acoustic stimulation or local application of glutamate agonists (Liberman and Mulroy, 1982; Robertson, 1983; Pujol et al., 1985, 1999; Zheng et al., 1997; Puel et al., 1998; Hakuba et al., 2000). It is believed that the afferent dendritic damage is caused by excessive release of neurotransmitter (most likely glutamate) from IHCs. A characteristic of these excitotoxic pathologies is the presence of massive swelling of afferent terminals under the IHCs. WT and $\mathrm{p}^{-1-}$ mice at ages of 1 and 3 months were processed for transmission electron microscopy. Electron microscopic features of the IHC subcellular synaptic region consist of intermingled afferent inner radial fibers and efferent spiral fibers as shown in a 3-month-old WT mouse (Fig. $3 A$ ). In a p $50^{-1-}$ mouse of the same age, vacuole-like spaces replace the afferent terminals of the inner radial nerves, but efferent terminals appear intact (Fig. 3B). The $\mathrm{p} 0^{-1-}$ mouse also shows membranous structures presumably representing residue from degenerating cell organelles. The cytoplasm in the base of the IHC consists of numerous vesicles infiltrated with normal-looking mitochondria and short profiles of cisternae (Fig. 3B). Figure $3 C$ shows edematous-appearing extracellular spaces between an IHC and supporting cell in another
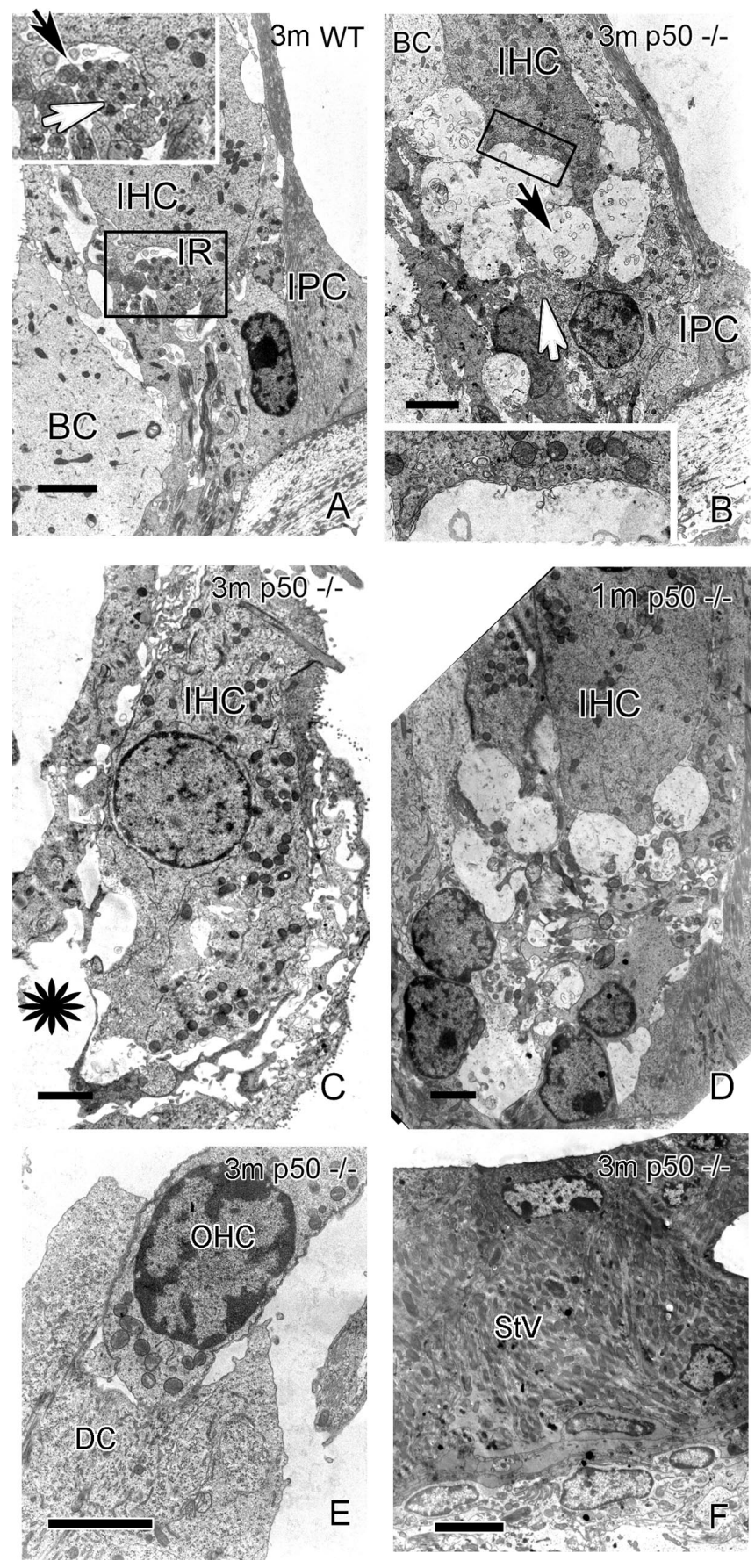

Figure 3. Afferent dendrites beneath IHCs in WT and $\mathrm{p} 50^{-1-}$ mice. Cochleas from a total of 15 WT and $\mathrm{p}^{-1-}$ mice at ages of 1 or 3 months were observed by electron microscopy (Table. 1). $\boldsymbol{A}$, Electron microscopic features of the basal half of an IHC and its subcellular synaptic region from the basal turn of a 3-month-old WT mouse. An inner pillar cell (IPC) and border cell (BC) surround the $\mathrm{IHC}$ and subadjacent nerves consisting of intermingled afferent inner radial fibers (IR; black arrow) and efferent spiral fibers (white arrow). $\boldsymbol{B}$, Vacuole-like spaces replace the

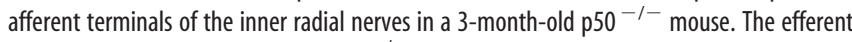
inner spiral fibers appear intact. The $5^{-1-}$ mice show membranous structures (black arrow), presumably representing residue from degenerated cell organelles. The cytoplasm in the base of the IHC consists of numerous small vesicles infiltrated with mitochondria and short profiles of cisternae. Efferent terminals (white arrow) appear normal. C, An IHC from another 3-month-old p50 ${ }^{-1-}$ mouse shows edematous-appearing extracellular spaces between the IHC and supporting cells (black asterisk). D, An IHC from a 1-month-old knock-out shows similar edematous-appearing spaces underlying the IHC. $\boldsymbol{E}, \mathrm{An} \mathrm{OHC}$ and underlying Deiters's cell (DC) from the basal turn of a 3-month-old $\mathrm{p}^{-1-} \mathrm{O}^{-1}$ mouse shows no pathologic change. The same cochlea is shown in $\boldsymbol{B}$. $\boldsymbol{F}$, The stria vascularia (StV) from the basal turn of a 3-month-old $\mathrm{p} 50^{-1-}$ mouse (same cochlea as in $\boldsymbol{B}$ ) shows no pathologic change. Scale bars: $\boldsymbol{A}-\boldsymbol{E}, 2 \mu \mathrm{m} ; \boldsymbol{F}, 3 \mu \mathrm{m}$. 


\section{$8 \mathrm{mWT}$}
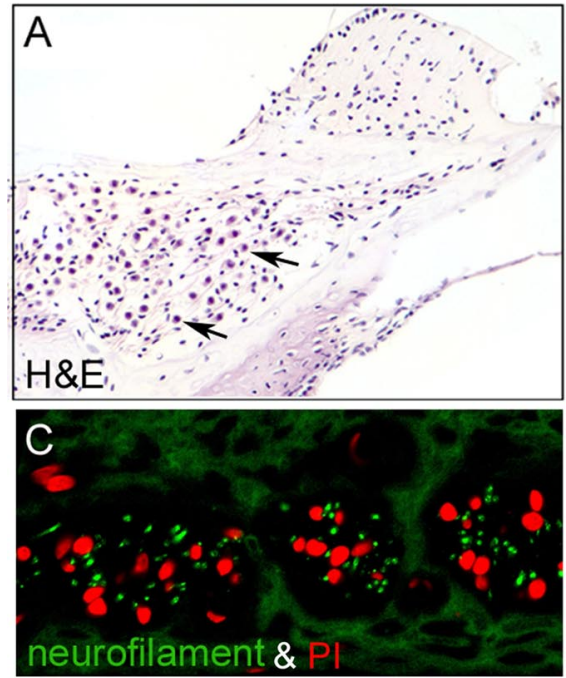

E

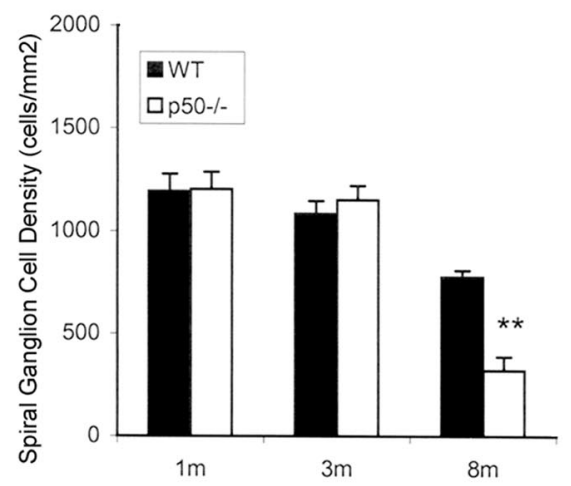

$8 \mathrm{~m} \mathrm{p} 50-/-$
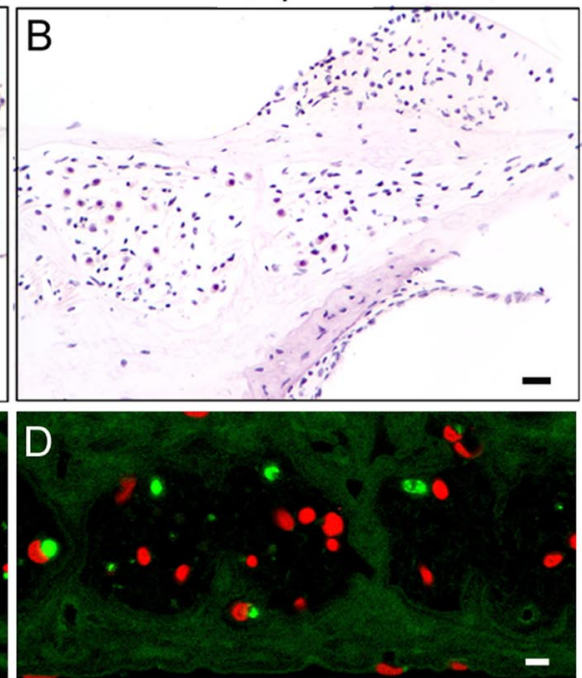

$\mathrm{F}$

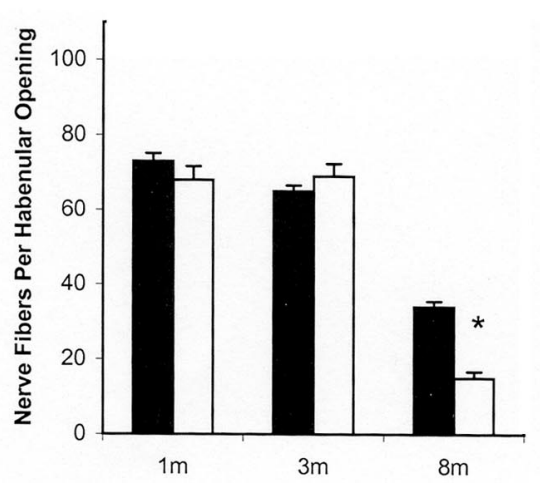

Figure 4. Age-related accelerated degeneration of SGN and nerve fibers in $\mathrm{p} 50^{-1-}$ mice. SGNs and nerve fibers were counted in sections through the basal turn from WT and $\mathrm{p}^{-1-}$ mice. $\boldsymbol{A}, \boldsymbol{B}$, Hematoxylin and eosin (H\&E)-stained sections of the basal turns from 8-month-old wild-type and knock-out mice show the profiles of SGNs with granular cytoplasm and the large spherical nuclei (arrows). The diminished number of SGNs in the basal turn is clearly evident in 8-month-old p50 ${ }^{-1-}$ mice. C, D, Peripheral axons of auditory fibers in 8-month-old WT and knock-out mice. The nerve fibers were labeled with neurofilament 200 (green), and nuclei were counterstained with PI (red). Photographs of tangential sections were taken through the osseous spiral lamina in the basal turn showing the groups of fibers. A significant loss of nerve fibers was seen in the basal turn of an 8-month-old p50 ${ }^{-1-}$ mouse. $\boldsymbol{E}$, SGN counts from 1-, 3-, and 8-month-old wild-type and knock-out mice ( $n=5$ for each group). Data are expressed as mean \pm SEM. The density of SGNs in the 8-month-old group was one-half that of the wild-type and was significantly different (ANOVA, ${ }^{* *} p<0.01$ ). There were no significant differences in the SGN densities between WT and $p 50^{-1-}$ mice in the 1- and 3-month-groups. $\boldsymbol{F}$, Average numbers of neurofilament 200-positive nerve fibers in each habenular opening from 1-, 3-, and 8-month-old WT and $p 50^{-1-}$ mice ( $n=4$ for each group). Data are expressed as mean \pm SEM. The number of nerve fibers per habenular opening in the 8-month-old group is significantly decreased compared with that of the wild-type mice (ANOVA, ${ }^{*} p<$ 0.05). Scale bars: (in $\boldsymbol{B}) \boldsymbol{A}, \boldsymbol{B}, 40 \mu \mathrm{m}$; (in $\boldsymbol{D}) \boldsymbol{C}, \boldsymbol{D}, 5 \mu \mathrm{m}$.

3-month-old $\mathrm{p}^{-1-}$ mouse. Pathologic lesions are also seen in a 1-month-old knock-out under an IHC (Fig. 3D). In contrast, no major pathologic changes were seen in OHCs or the stria vascularis in 1 - and 3-month-old p50 ${ }^{-1-}$ and WT mice. Figure 3, E and $F$, shows the relatively normal appearance of an $\mathrm{OHC}$ and the stria vascularis, despite the presence of marked excitotoxic changes in the same cochlea (Fig. 3B).

Excitotoxic pathologies of afferent dendrites under the IHCs were found in cochleas of all six p50 ${ }^{-1-}$ mice and in only four of nine WT mice. We counted the number of swollen dendritic terminals per IHC region in the basal turns of cochleas from 1and 3-month-old WT and p50 ${ }^{-1-}$ mice (Table 1). The number of swollen dendritic terminals per IHC region in $\mathrm{p} 50^{-/-}$mice was significantly higher than that found in WT mice (ANOVA, $p<$ $0.05)$.
There are two subpopulations of neurons in the spiral ganglion of the mammalian cochleas. The large type I fibers innervating the IHCs represent $~ 90-95 \%$ of the afferent auditory neurons and are myelinated. The remaining small type II neurons with peripheral processes synapse on IHCs and are unmylinated (Spoendlin, 1969). The swollen afferent terminals were seen only below the IHCs but not the $\mathrm{OHCs}$, indicating that pathologies of the

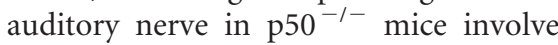
type I ganglion neurons, not type II neurons.

\section{Progressive degeneration of SGNs and} afferent nerve fibers in $\mathrm{p}^{5} \mathrm{0}^{-/-}$mice To define the morphological basis for the accelerated hearing loss with age in the p50 $0^{-1-}$ mice, especially at higher frequencies (Fig. 1), we examined basal SGN pathology by quantifying the cell density of SGNs and the number of afferent fibers in each habenular opening using light microscopy. There are two populations of afferent neurons in the mammalian cochlea. Large type I neurons with peripheral processes synapsing on IHCs represent $\sim 90$ 95\% of the SGNs. The remaining smaller type II cells synapse on OHCs. For auditory nerve fiber counts, neurofilament 200positive afferent fibers were examined in sections containing the osseous spiral lamina. The monoclonal anti-neurofilament 200 (Sigma; clone N52, N 0142, phosphorylated and nonphosphorylated) labeled both type I and type II neurons and their processes in $\mathrm{WT}$ and $\mathrm{p} 50^{-1-}$ mice. Our observations are in agreement with the immunohistochemical studies of Mou et al. (1998) and Adamson et al. (2002) in mouse SGNs using the same antibody.

We quantified the cell density of SGNs in the basal cochleas of WT and $\mathrm{p} 50^{-1-}$ mice at 1, 3, and 8 months of age (Figs. $4 A, B, E)$. The cell density of SGNs in p50 $0^{-1-}$ mice was relatively constant from 1 to 3 months of age, similar to those in WT mice. At 8 months of age, considerable SGN degeneration was present in both WT and p50 $0^{-1-}$ mice. The basal cochleas of WT mice at 8 months of age had lost $\sim 28 \%$ of their SGNs. These data are in agreement with previous studies in C57BL/6J mice where the basal cochlea showed $\sim 32 \%$ loss of SGNs at 12 months of age (Idrizbegovic et al., 2003). In the 8-month-old p50 ${ }^{-1-}$ mice, the basal cochlea had a $69 \%$ loss of SGNs. The density of SGNs in the knock-outs was about one-half that of the WT mice, and the difference was significant (ANOVA, $p<0.01$ ).

All afferent nerve fibers enter the organ of Corti through the habenulae perforata in the osseous spiral lamina. Neurofilament 200-positive afferent axons were seen in tangential sections through the osseous spiral lamina (Figs. 4C,D). Quantitative analysis in the basal turn showed that the numbers of afferent axons per habenular opening in the 8 -month-old $\mathrm{p}^{-1-}$ mice 
were significantly decreased compared with those of WT mice (Fig. $4 F$ ) (ANOVA, $p<0.05$ ).

We also evaluated IHC and OHC survival with surface preparations of the basilar membrane in ${\mathrm{p} 50^{-1-}}^{-1}$ and WT mice (Fig. 5 ). There was no significant reduction in number of IHC and $\mathrm{OHC}$ in 1-month-old $\mathrm{p} 50^{-1-}$ mice compared with WT mice. By 8 months of age, there was a significant reduction in the number of basal OHCs in both WT and $\mathrm{p}^{-1-}$ mice compared with 1 -month-old WT mice (Fig. 5D) (ANOVA, $p<0.05$ ). However, no significant differences in $\mathrm{OHC}$ numbers were found between WT and $\mathrm{p}^{-1-}$ mice at either 1 or 8 months of age. Moreover, no significant loss of IHCs was found in either WT or $\mathrm{p} 50^{-1-}$ mice at 8 months of age (Fig. $5 E$ ) (ANOVA, $p>0.05$ ).

Increased intensity of immunostaining for calcium-buffering proteins in $\mathrm{p}^{50^{-1-}}$ mice

Calcium-buffering proteins play an important role in $\mathrm{Ca}^{2+}$ homeostasis. Previous studies in striatal neurons have shown that excitotoxic injury causes a rise in intracellular calcium and an increased immunoreactivity to calcium-buffering proteins (Huang et al., 1995). Numerous animal and human studies have shown the presence of a variety of calcium-buffering proteins in neural structures of the organ of Corti and SGNs including NCS1, PMCA3, calbindin D28K, and synaptophysin (Rehm et al., 1986; Liberman et al., 1990; Nadol and Burgess, 1994; Crouch and Schulte, 1995; Counter et al., 1997; Milosevic and Zecevic, 1998; Coppens et al., 2000; Sage et al., 2000; Imamura and Adams, 2003; Khalifa et al., 2003). To further characterize the cellular abnormalities in the SGNs of $\mathrm{p} 50^{-1-}$ mice, we compared the expression of NCS1, PMCA3, calbindin D28K, and synaptophysin in three 8-month-old WT and three $\mathrm{p}^{-1-}$ mice using immunohistochemistry (Fig. 6). The SGNs in WT and $\mathrm{p}^{-1-}$ mice were positive for all four examined antibodies. Immunostaining for NCS1 and PMCA3 appeared as a uniform cytoplasm pattern, although the latter staining was weaker. Calbindin D28K was present in both the cytoplasm and nuclei of SGNs. Punctuate immunostaining for synaptophysin was seen in the cytoplasm of SGNs. The immunostaining intensities for all four proteins in SGNs were significantly increased in $\mathrm{p} 50^{-1-}$ mice compared with WT mice (ANOVA, ${ }^{\star} p<0.05 ;{ }^{\star *} p<0.01$ ).

\section{Increased cochlear vulnerability to noise-induced hearing} loss in $\mathrm{p}^{50^{-/-}}$mice

We chose 1-month-old mice for the noise-exposure experiment because CAP thresholds at this age are relatively similar for WT and $\mathrm{p} 0^{-1-}$ mice (Fig. 1). After $2 \mathrm{~h}$ of exposure to a wideband, low-level noise at $70 \mathrm{~dB}$ SPL, there were no significant CAP threshold shifts in WT mice (Fig. 7). In contrast, the same exposure caused 7-15 dB SPL threshold shifts across most frequencies tested in $\mathrm{p} 0^{-1-}$ mice (Fig. 7). These data suggest that $\mathrm{p} 50^{-1-}$ mice have an increased sensitivity to noise injury.

\section{Discussion}

Numerous studies have shown that $\mathrm{NF} \kappa \mathrm{B}$ activity is required for neuronal survival under both physiological and pathological conditions (Yu et al., 1999; Mattson et al., 2000; Blondeau et al., 2001; Pennypacker et al., 2001; Bhakar et al., 2002; Kassed et al., 2002; Aleyasin et al., 2004). NF $\kappa \mathrm{B}$ activity is greatly increased when brain cells suffer excitotoxic and apoptotic insults. In the cochlea, previous studies have provided direct evidence of activation of $\mathrm{NF} \kappa \mathrm{B}$ in response to injury, as determined by electrophoretic shift assays. NF $\kappa \mathrm{B}$ activity was elevated in chinchilla cochleas after exposure to a $96 \mathrm{~dB}$ octave band noise for $6 \mathrm{~h}$, and
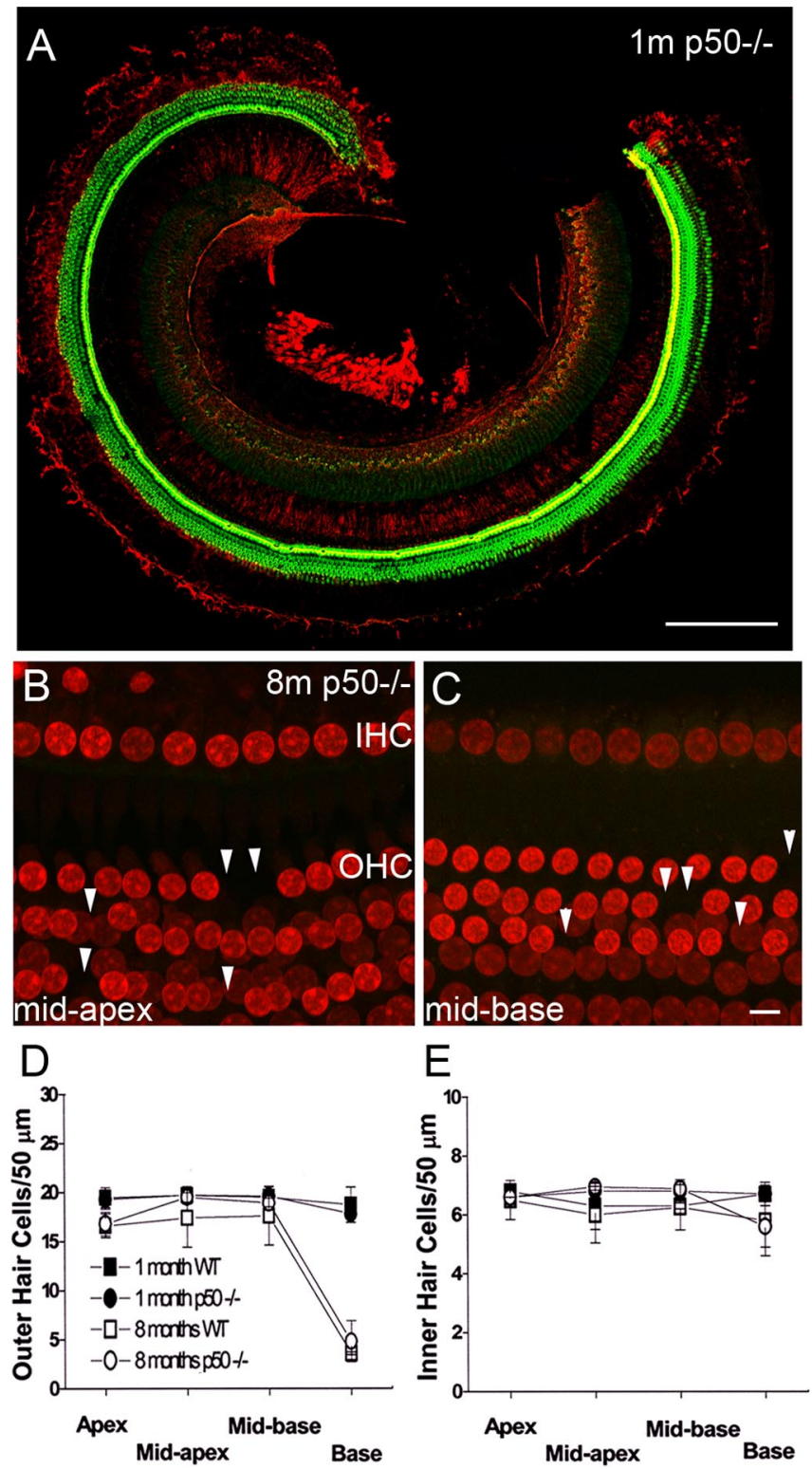

Figure 5. Deficiency of the $\mathrm{p} 50$ subunit of NF $\kappa$ B has little effect on hair-cell survival. Data are represented as mean \pm SEM. $\mathrm{OHC}$ and IHC densities at defined cochlear locations in 1- and

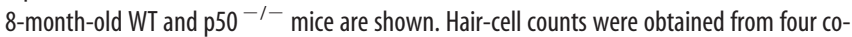
chleas of 1-month-old WT mice, four cochleas of 1-month-old knock-outs, six cochleas of 8-month-old WT mice, and six cochleas of 8-month-old knock-outs. All three rows of OHCs were included in the $\mathrm{OHC}$ counts. $\boldsymbol{A}$, LoW-magnification view of the surface preparation of the basilar membrane showing filamentous actin-positive stereocilia bundles (green) on $\mathrm{HHCs}$ and $\mathrm{OHCs}$ as well as apical region of supporting cells. SGNs were stained red with anti-neurofilament 200. The image shows the apical half of the cochlea from a 1-month-old p50 ${ }^{-1-}$ mouse. $\boldsymbol{B}, \boldsymbol{C}$, Higher-magnification view of the surface preparation shows the nuclei of $\mathrm{IHCs}$ and $\mathrm{OHCs}$ stained with PI (red). Images were taken from the mid-apical turn $(\boldsymbol{B})$ and mid-basal turn of an 8-month-old $\mathrm{p} \mathrm{O}^{-1-}$ mouse. Missing $\mathrm{OHC}$ are shown with arrowheads. D, A significant loss of $\mathrm{OHCs}$ was present in the basal turns of the 8-month-old WT and knock-out mice as compared with 1-month-old WT mice (ANOVA, $p<0.01$ ). However, OHC losses were similar in knock-outs and WT mice of the same age (ANOVA, $p>0.05$ ). $\boldsymbol{E}$, No significant loss of IHCs with age was found in either WT or $p 50^{-1-}$ mice (ANOVA, $p>0.05$ ). IHC density differences between wild-type and knock-out mice were not statistically significant at ages of 1 and 8 months, respectively (ANOVA, $p>0.05$ ). Scale bars: $\boldsymbol{A}, 250 \mu \mathrm{m}$; (in C) $\boldsymbol{B}, \boldsymbol{C}, 10 \mu \mathrm{m}$.

in mouse cochleas after exposure to lipopolysaccharide and the ototoxic aminoglycoside kanamycin (Wu and Xie, 2002; Ramkumar et al., 2004; Jiang et al., 2005). A recent study showed that selective inhibition $\mathrm{NF} \kappa \mathrm{B}$ caused apoptosis of immature hair cells 

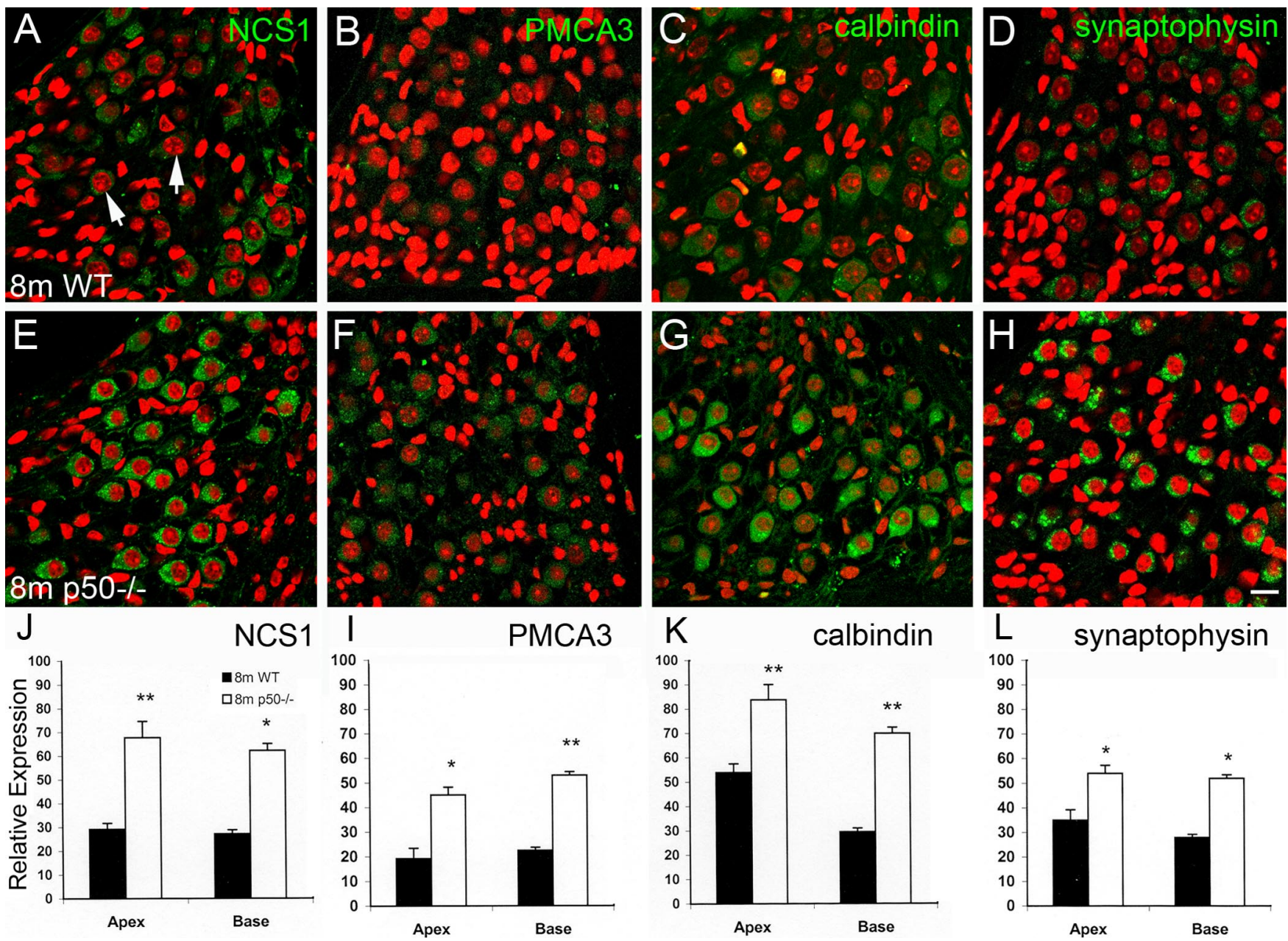

Figure 6. The immunoreactivity for a set of calcium-buffering proteins is markedly increased in p50 ${ }^{-1-}$ mice. Immunohistochemical staining for NCS1, PMCA3, calbindin D28K, and synaptophysin (green) was performed on paraffin sections of 8-month-old WT and $\mathrm{p5}^{-1-}$ mice. Nuclei were counterstained with PI (red). Ganglion cells were identified by their large spherical nucleus (white arrows). All images were taken from cochlear apical turns. $A, E$, SGNs show a uniform cytoplasm staining for NCS1. $B, F$, Anti-PMCA3 shows punctuate staining in cytoplasm of SGNs. $C, G$, Anti-calbindin D28K shows uniform cytoplasm and weak nuclei staining in SGNs. D, $\boldsymbol{H}$, SGNs reveal a punctuate staining pattern for synaptophysin. Scale bar: (in $\boldsymbol{H}) \boldsymbol{A}-\boldsymbol{H}, 20 \mu \mathrm{m}$. $\boldsymbol{J}-\boldsymbol{L}, \mathrm{T}$, The relative intensities of immunostaining for NCS1, PMCA3, calbindin D28K, and synaptophysin in both the apical and basal cochlea are significantly increased in p50 ${ }^{-1-}$ mice compared with WT mice. (ANOVA, $\left.{ }^{*} p<0.05 ;{ }^{* *} p<0.01\right)$. Data are represented as mean \pm SEM.

in vitro (Nagy et al., 2005). However, there is little information regarding activation of $\mathrm{NF} \kappa \mathrm{B}$ in the auditory nerve and how $\mathrm{NF} \kappa \mathrm{B}$ activity may affect cochlear function with age and trauma. Here, mice lacking the $\mathrm{p} 50$ subunit of $\mathrm{NF} \kappa \mathrm{B}\left(\mathrm{p} 50^{-1-}\right.$ mice) showed an accelerated hearing loss with age that was highly associated with an exacerbated excitotoxic-like damage in afferent dendrites under IHCs and an accelerated loss of SGNs.

In the cochlea, excitotoxic pathology occurs in response to a variety of injuries. Local application of ouabain and glutamate agonists, kainic acid, or $\alpha$-amino-3-hydroxy-5-methyl-4isoxazolepropionic acid can cause an immediate and massive swelling of the radial afferent dendrites under IHCs (Pujol et al., 1985; Zheng et al., 1997; Puel et al., 1998; Spicer et al., 2002). Here, excitotoxic-like pathologies of afferent dendrites under IHCs were found in $100 \%$ of the examined p $50^{-/-}$mice and only $44 \%$ of the WT mice. The average number of swollen afferent dendrites under IHCs in $\mathrm{p}^{-1-}$ mice was significantly higher than that of WT mice. These data strongly suggest that deficiency of the p50 subunit of NF $\kappa \mathrm{B}$ increases auditory nerve susceptibility to excitotoxicity.

Although there is not a significant loss of SGNs in 1- and

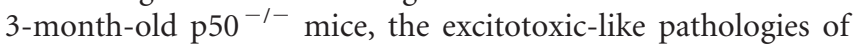

afferent dendrites under IHCs are the most likely morphological evidence for the cause of the elevated CAP thresholds in the knock-outs. Hearing loss has been associated with the swollen afferent dendrites under IHCs as in mice lacking the glutamate transporter GLAST after sound exposure, in chinchillas after kainic acid excitotoxicity, in guinea pigs after sound exposure, and after intra-cochlear infusion of the aminoglycoside antibiotic amikacin and the glutamate agonist AMPA ( $\alpha$-amino-3hydroxy-5-methyl-4-isoxazolepropionic acid) (Robertson, 1983; Zheng et al., 1997; Puel et al., 1998; Duan et al., 2000; Hakuba et al., 2000; Le Prell et al., 2004). Studies have also shown that functional recovery corresponds to structural recovery or reestablishment of the IHC/auditory-nerve synapse after acute excitotoxic-drug exposures (Zheng et al., 1997; Pujol and Puel 1999; X. Y. Zheng et al., 1999; Le Prell et al., 2004).

The disturbance of calcium homeostasis is a major event associated with excitotoxicity in neurons. Excessive synaptic release of glutamate can lead to the disregulation of calcium homeostasis (Arundine and Tymianski, 2003). Disturbances of calcium homeostasis induced by various insults play an important role in pathological processes, culminating in neuronal apoptosis and excitotoxicity (Mattson et al., 2000; Mattson and Chan, 2001). To 

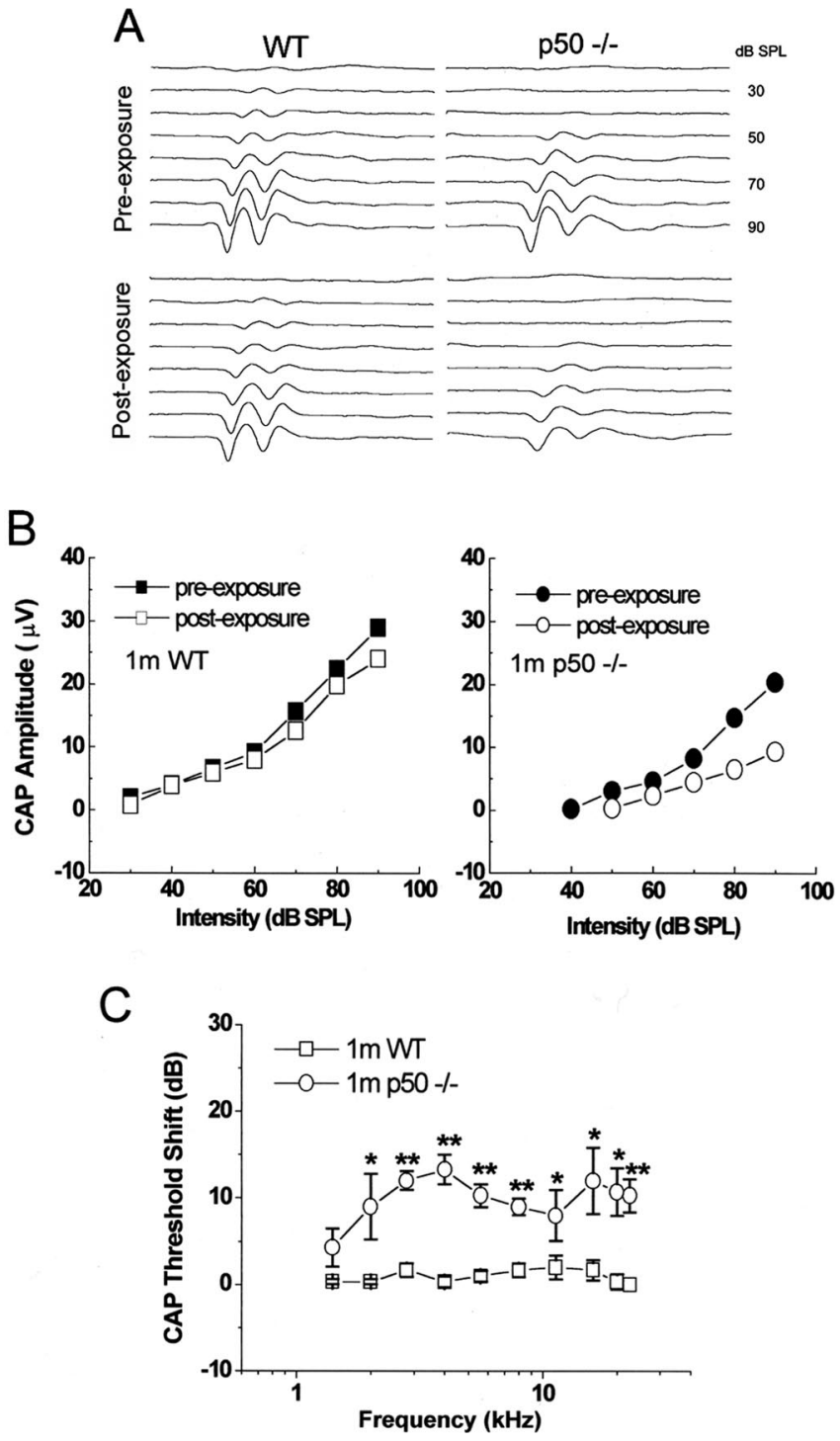

Figure 7. Increased susceptibilities to noise-induced hearing loss in $\mathrm{p}^{-1-} 0^{-1}$ mice. A, An intensity series of CAP responses from a WT mouse (left) showed no threshold shifts immediately after a $2 \mathrm{~h}$ wideband exposure to a low-level noise (70 dB SPL). However, the CAP responses from a $\mathrm{p}^{-1-}$ mouse were shifted by $\sim 10 \mathrm{~dB}$ at $16 \mathrm{kHz}$ after a similar exposure. $\boldsymbol{B}$, CAP I/0 functions plotting the CAP peak amplitude as a function of the intensity of acoustic probe tones at $16 \mathrm{kHz}$. Data are from the animal shown in $A$. The CAP $/ / 0$ function obtained from a p $50^{-1-}$ ear shows a reduced slope after the $2 \mathrm{~h}$ noise exposure. C, CAP threshold shifts in

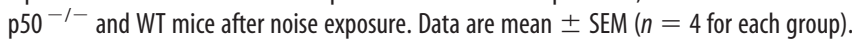
ANOVA, ${ }^{*} p<0.05,{ }^{* *} p<0.01$.

further investigate the cellular mechanisms underlying the progressive SGN pathology in $\mathrm{p} 50^{-1-}$ mice, we evaluated changes in the expression of a set of calcium-buffering proteins with immunohistochemistry. These proteins included NCS1, PMCA3, calbindin D28K, and synaptophysin, all of which are involved in calcium-regulating processes in mammalian SGNs (Rehm et al., 1986; Liberman et al., 1990; Nadol and Burgess, 1994; Crouch and Schulte, 1995; Counter et al., 1997; Milosevic and Zecevic 1998; Coppens et al., 2000; Sage et al., 2000; Imamura and Adams, 2003; Khalifa et al., 2003). NCS1, also named as frequenin, is a highly conserved member of the elongation factor-hand calciumbinding protein family expressed mainly in neurons (Braunewell and Gundelfinger, 1999). PMCA is a plasma membraneassociated calcium pump that transports calcium ions out of the cell by using the energy stored in ATP. PMCA is essential for control of cytosolic calcium concentrations (Carafoli, 1991). Calbindin D28K is believed to function as an intracellular calcium buffer and has been localized in several neuronal populations within the CNS as well as SGNs (Celio, 1990; Slepecky and Ulfendahl, 1993). Synaptophysin is a well known marker for synaptic vesicles and is present in auditory nerve terminals in the organ of Corti. It can also act as a calcium-binding protein and is expressed in SGNs of the mammalian cochlea (Anniko et al., 1995; Rask-Andersen et al., 2000; Khalifa et al., 2003).

The increased expression of NCS1, PMCA3, calbindin D28K and synaptophysin in SGNs of knock-out mice, as demonstrated here, strongly suggests a disturbance in their calcium homeostatic mechanisms. The disturbance of calcium homeostasis may be an important cause of the rapid age-related SGN degeneration in $\mathrm{NF} \kappa \mathrm{B}$ deficient mice compared with the WT. The increased intensity of immunostaining for calcium regulatory proteins in this mutant mouse may be the result of an overall decrement of neuronal viability, or upregulating gene products that regulate $\mathrm{Ca}^{2+}$ homeostasis by the deficiency of $\mathrm{NF} \kappa \mathrm{B}$ activity. Several studies have documented that activation of $\mathrm{NF} \kappa \mathrm{B}$ is required to maintain calcium homeostasis and modulate cell death. Cultured striatal neurons from $\mathrm{p} 50^{-1-}$ mice exhibit perturbed calcium regulation and increased cell death after exposure to mitochondrial toxins (Yu et al., 2000). Inhibition of $\mathrm{NF} \kappa \mathrm{B}$ activity in PC12 cells by treatment with $\kappa \mathrm{B}$ decoy DNA is associated with enhanced elevation of intracellular calcium levels induced by the neurotoxic amyloid $\beta$-peptide (Guo et al., 1998). Moreover, fibroblasts lacking the subunit of $\mathrm{NF} \kappa \mathrm{B}$ p65 exhibit increased inositol 1,4,5trisphosphate $\left(\mathrm{IP}_{3}\right)$ receptor-mediated calcium release from the endoplasmic reticulum (ER) and increased sensitivity to apoptosis (Camandola et al., 2005).

However, $\mathrm{Ca}^{2+}$ release from $\mathrm{IP}_{3}$-sensitive ER stores can also trigger activation of $\mathrm{NF} \kappa \mathrm{B}$ in cultured neurons (Glazner et al., 2001). A recent study showed that synaptic transmission can activate $\mathrm{NF} \kappa \mathrm{B}$ via local submembranous $\mathrm{Ca}^{2+}$ increases along with a pathway requiring $\mathrm{Ca}^{2+} /$ calmodulin-dependent kinase (CaMKII) under physiological conditions (Meffert et al., 2003). Therefore, NF $\kappa \mathrm{B}$ may participate in a dynamic transcriptiondependent feedback mechanism to control $\mathrm{Ca}^{2+}$ homeostasis in both physiological and pathological conditions.

In noise-induced hearing loss, it is thought that excitotoxic damage to afferent neurons can contribute to acute threshold shifts (Robertson, 1983; Puel et al., 1998). Damage to afferent fibers beneath IHCs after acoustic stimulation has been reported in numerous studies (Spoendlin, 1971; Liberman and Mulroy, 1982; Robertson, 1983; Puel et al., 1996, 1998). We exposed the 1 -month-old $\mathrm{p}^{-1-}$ and WT mice to $70 \mathrm{~dB}$ SPL wideband noise for $2 \mathrm{~h}$. The low-level noise did not produce a threshold shift in WT mice, consistent with previous studies showing that a temporary threshold shift induced by octave-band noise requires an exposure intensity of at least $94 \mathrm{~dB}$ SPL (Wang et al., 2002; Hirose and Liberman, 2003). However, CAP thresholds were shifted $\sim 7-15 \mathrm{~dB}$ SPL across most frequencies tested in the $\mathrm{p} 50^{-/-}$mice with the same exposure paradigm. These results indicate that $\mathrm{p} 50^{-1-}$ mice are more sensitive to acoustic exposure than WT mice.

The p50 knock-outs were generated with a C57BL/6 background, a strain that is a well known model for age-related hearing loss. The decline of hearing sensitivity in the C57BL/ 6 begins at high frequencies and is caused mainly by the loss of hair cells, some loss of SGNs, and a loss of type IV fibrocytes (Spongr et al., 1997; White et al., 2000; Hequembourg and Liberman, 2001; 
Ohlemiller and Gagnon, 2004). Our results do demonstrate a significant reduction of basal SGNs and OHCs in both WT and p50 $0^{-1-}$ mice at 8 months of age. However, the degeneration of SGNs and afferent-nerve fibers was significantly greater in the p50 $0^{-1-}$ mice and occurred without an accompanying increased loss of IHCs or OHCs in the knock-out mice compared with WT mice. Thus, the protective effect of $\mathrm{NF} \kappa \mathrm{B}$ activation in cochlea seems to be specific to the primary auditory nerve under normal physiological conditions. In the CNS, there is a low-level constitutive activity of $\mathrm{NF} \kappa \mathrm{B}$ in neurons (Kaltschmidt et al., 1994). It is possible that the activation of $\mathrm{NF} \kappa \mathrm{B}$ is also involved in the survival of the central auditory nerve system. Additional studies need to be performed using physiological and morphological methods in the central auditory nerve system of $\mathrm{p}^{-1-}$ mice.

The purpose for performing the experiments herein was to gain additional insights into the mechanisms regulating auditory nerve survival and degeneration. The $\mathrm{p} 50^{-1-}$ knock-out mouse provides a unique model for studying mechanisms of SGN degeneration occurring with noise exposure, ototoxic drugs, or age. A more complete understanding of the functional role of $\mathrm{NF} \kappa \mathrm{B}$ in regulating the survival and death of auditory SGNs may provide new therapeutic strategies to prevent or ameliorate hearing loss caused by various injuries and to preserve the residual hearing in cochlear implant users.

\section{References}

Adamson CL, Reid MA, Davis RL (2002) Opposite actions of brain-derived neurotrophic factor and neurotrophin-3 on firing features and ion channel composition of murine spiral ganglion neurons. J Neurosci 22:1385-1396.

Aleyasin H, Cregan SP, Iyirhiaro G, O’Hare MJ, Callaghan SM, Slack RS, Park DS (2004) Nuclear factor- $\kappa \mathrm{B}$ modulates the $\mathrm{p} 53$ response in neurons exposed to DNA damage. J Neurosci 24:2963-2973.

Anniko M, Arnold W, Stigbrand T, Strom A (1995) The human spiral ganglion. ORL J Otorhinolaryngol Relat Spec 57:68-77.

Arundine M, Tymianski M (2003) Molecular mechanisms of calciumdependent neurodegeneration in excitotoxicity. Cell Calcium 34:325-337.

Bao J, Lei D, Du Y, Ohlemiller KK, Beaudet AL, Role LW (2005) Requirement of nicotinic acetylcholine receptor subunit $\beta 2$ in the maintenance of spiral ganglion neurons during aging. J Neurosci 25:3041-3045.

Bhakar AL, Tannis L, Zeindler C, Russo MP, Jobin C, Park DS, MacPherson S, Barker PA (2002) Constitutive nuclear factor- $\kappa \mathrm{B}$ activity is required for central neuron survival. J Neurosci 22:8466-8475.

Blondeau N, Widmann C, Lazdunski M, Heurteaux C (2001) Activation of the nuclear factor- $\kappa \mathrm{B}$ is a key event in brain tolerance. J Neurosci 21:4668-4677.

Bodmer D, Gloddek B, Ryan AF, Huverstuhl J, Brors D (2002) Inhibition of the c-Jun $\mathrm{N}$-terminal kinase signaling pathway influences neurite outgrowth of spiral ganglion neurons in vitro. Laryngoscope 112:2057-2061.

Bok J, Zha X, Cho Y, Green SH (2003) An extranuclear locus of cAMPdependent protein kinase action is necessary and sufficient for promotion of spiral ganglion neuronal survival by cAMP. J Neurosci 23:777-787.

Braunewell KH, Gundelfinger ED (1999) Intracellular neuronal calcium sensor proteins: a family of EF-hand calcium-binding proteins in search of a function. Cell Tissue Res 295:1-12.

Camandola S, Cutler RG, Gary DS, Milhavet O, Mattson MP (2005) Suppression of calcium release from inositol 1,4,5-trisphosphate-sensitive stores mediates the anti-apoptotic function of nuclear factor- $\kappa$ B. J Biol Chem 280:22287-22296.

Carafoli E (1991) The calcium pumping ATPase of the plasma membrane. Annu Rev Physiol 53:531-547.

Celio MR (1990) Calbindin D-28k and parvalbumin in the rat nervous system. Neuroscience 35:375-475.

Coppens AG, Resibois A, Poncelet L (2000) Immunolocalization of calbindin D28k and calretinin in the dog cochlea during postnatal development. Hear Res 145:101-110.

Counter SA, Canlon B, Borg E, Aldskogius H (1997) Pattern of synaptophysin immunoreactivity in the efferent nerve terminals of the guinea pig cochlea. Neurosci Lett 222:199-203.
Crouch JJ, Schulte BA (1995) Expression of plasma membrane Ca-ATPase in the adult and developing gerbil cochlea. Hear Res 92:112-119.

Ding D, McFadden SL, Salvi RJ (2001) Cochlear hair cell densities and inner-ear staining techniques. In: Handbook of mouse auditory research (Willott JF, ed), pp 189-204. New York: CRC.

Dodson HC (1997) Loss and survival of spiral ganglion neurons in the guinea pig after intracochlear perfusion with aminoglycosides. J Neurocytol 26:541-556.

Duan M, Agerman K, Ernfors P, Canlon B (2000) Complementary roles of neurotrophin 3 and a $N$-methyl-D-aspartate antagonist in the protection of noise and aminoglycoside-induced ototoxicity. Proc Natl Acad Sci USA 97:7597-7602.

Engström H (1958) Structure and innervation of the inner ear sensory epithelia. Int Rev Cytol 7:535-585.

Glazner GW, Camandola S, Geiger JD, Mattson MP (2001) Endoplasmic reticulum D-myo-inositol 1,4,5-trisphosphate-sensitive stores regulate nuclear factor- $\kappa \mathrm{B}$ binding activity in a calcium-independent manner. J Biol Chem 276:22461-22467.

Green SH (2000) Neurotrophic signaling by membrane electrical activity in spiral ganglion neurons. In: Cell and molecular biology of the ear (Lim DJ, ed), pp 165-182. New York: Kluwer Academic/Plenum.

Guo Q, Robinson N, Mattson MP (1998) Secreted $\beta$-amyloid precursor protein counteracts the proapoptotic action of mutant presenilin-1 by activation of NF $\kappa \mathrm{B}$ and stabilization of calcium homeostasis. J Biol Chem 273:12341-12351.

Hakuba N, Koga K, Gyo K, Usami S, Tanaka K (2000) Exacerbation of noise-induced hearing loss in mice lacking the glutamate transporter GLAST. J Neurosci 20:8750-8753.

Hansen MR, Bok J, Devaish AK, Zha X-M, Green SH (2003) $\mathrm{Ca}^{2+} /$ calmodulin-dependent protein kinases II and IV both promote survival but differ in their effects on axon growth in spiral ganglion neurons. J Neurosci Res 72:169-184.

Hanson Jr MG, Shen S, Wiemelt AP, McMorris FA, Barres BA (1998) Cyclic AMP elevation is sufficient to promote the survival of spinal motor neurons in vitro. J Neurosci 18:7361-7371.

Hequembourg S, Liberman MC (2001) Spiral ligament pathology: a major aspect of age-related cochlear degeneration in C57BL/6 mice. J Assoc Res Otolaryngol 2:118-129.

Hirose K, Liberman MC (2003) Lateral wall histopathology and endocochlear potential in the noise-damaged mouse cochlea. J Assoc Res Otolaryngol 4:339-352.

Horner KC, Lenoir M, Bock GR (1985) Distortion product otoacoustic emissions in hearing-impaired mutant mice. J Acoust Soc Am 78:1603-1611.

Huang Q, Zhou D, Sapp E, Aizawa H, Ge P, Bird ED, Vonsattel JP, DiFiglia M (1995) Quinolinic acid-induced increases in calbindin D28k immunoreactivity in rat striatal neurons in vivo and in vitro mimic the pattern seen in Huntington's disease. Neuroscience 65:397-407.

Idrizbegovic E, Bogdanovic N, Viberg A, Canlon B (2003) Auditory peripheral influences on calcium binding protein immunoreactivity in the cochlear nucleus during aging in the C57BL/6J mouse. Hear Res 179:33-42.

Imamura S, Adams JC (2003) Change in cytochemistry of sensory and nonsensory cells in gentamicin-treated cochleas. J Assoc Res Otolaryngol 4:196-218.

Jiang H, Sha SH, Schacht J (2005) NF- $\kappa$ B pathway protects cochlear hair cells from aminoglycoside-induced ototoxicity. J Neurosci Res 79:644-651.

Kaltschmidt C, Kaltschmidt B, Neuman H, Wekerle H, Baeuerle PA (1994) Constitutive NF- $\kappa$ B activity in neurons. Mol Cell Biol 14:3981-3992.

Kassed CA, Willing AE, Garbuzova-Davis, Sanberg PR, Pennypacker KR (2002) Lack of NF- $\kappa \mathrm{B}$ p50 exacerbates degeneration of hippocampal neurons after chemical exposure and impairs learning. Exp Neurol 176:277-288.

Keithley EM, Feldman ML (1979) Spiral ganglion cell counts in an agegraded series of rat cochleas. J Comp Neurol 188:429-442.

Khalifa SAM, Friberg U, Illing RB, Rask-Andersen H (2003) Synaptophysin immunohistochemistry in the human cochlea. Hear Res 185:34-42.

Kiang NYS, Liberman MC, Levine RA (1976) Auditory-nerve activity in cats exposed to ototoxic drugs and high-intensity sound. Ann Otol Rhinol Laryngol 85:752-768.

Kimura RS (1984) Sensory and accessory epithelia of the cochlea. In: Ultrastructural atlas of the inner ear (Friedmann I, Ballantyne J, eds), pp 101132. London: Butterworths.

Lallemend F, Lefebvre PP, Hans G, Rigo JM, Van de Water TR, Moonen G, 
Malgrange B (2003) Substance P protects spiral ganglion neurons from apoptosis via PKC-Ca ${ }^{2+}$-MAPK/ERK pathways. J Neurochem 87:508-521.

Lang H, Schulte BA, Schmiedt RA (2002) Endocochlear potential and compound action potential recovery function in the C57BL/6J mouse. Hear Res 172:118-126.

Lang H, Schulte BA, Schmiedt RA (2005) Ouabain induces apoptotic cell death in type I spiral ganglion neurons, but not type II neurons. J Assoc Res Otolaryngol 6:63-74.

Leak PA, Hradek GT (1988) Cochlear pathology of long term neomycin induced deafness in cats. Hear Res 33:11-34.

Le Prell CG, Yagi M, Kawamoto K, Beyer LA, Atkin G, Raphael Y, Dolan DF, Bledsoe Jr SC, Moody DB (2004) Chronic excitotoxicity in the guinea pig cochlea induces temporary functional deficits without disrupting otoacoustic emissions. J Acoust Soc Am 116:1044-1056.

Liberman MC, Mulroy MJ (1982) Acute and chronic effects of acoustic trauma: cochlear pathology and auditory nerve pathophysiology. In: New perspectives on noise-induced hearing loss (Hamernik RP, Henderson D, Salvi R, eds), pp 105-151. New York: Raven.

Liberman MC, Dodds LW, Pierce S (1990) Afferent and efferent innervation of the cat cochlea: quantitative analysis with light and electron microscopy. J Comp Neurol 301:443-460.

Mattson MP (2003) Excitotoxic and excitoprotective mechanisms: abundant targets for the prevention and treatment of neurodegenerative disorders. Neuromol Med 3:65-94.

Mattson MP, Chan SL (2001) Dysregulation of cellular calcium homeostasis in Alzheimer's disease: bad genes and bad habits. J Mol Neurosci 17:205-224.

Mattson MP, Culmsee C, Yu Z, Camandola S (2000) Roles of nuclear factor $\kappa \mathrm{B}$ in neuronal survival and plasticity. J Neurochem 74:443-456.

Meffert MK, Chang JM, Wiltgen BJ, Fanselow MS, Baltimore D (2003) $\mathrm{NF}-\kappa \mathrm{B}$ functions in synaptic signaling and behavior. Nat Neurosci 6:1072-1078

Milosevic A, Zecevic N (1998) Developmental changes in human cerebellum: expression of intracellular calcium receptors, calcium-binding proteins, and phosphorylated and nonphosphorylated neurofilament protein. J Comp Neurol 396:442-460.

Mou K, Adamson CL, Davis RL (1998) Time-dependence and cell-type specificity of synergistic neurotrophin actions on spiral ganglion neurons. J Comp Neurol 402:129-139.

Nadol JB, Burgess BJ (1994) Supranuclear efferent synapses on outer hair cells and Deiter's cells in the human organ of Corti. Hear Res 81:49-56.

Nagy I, Monge A, Albinger-Hegyi A, Schmid S, Bodmer D (2005) NF- $\kappa$ B is required for survival of immature auditory hair cells in vitro. J Assoc Res Otolaryngol 6:260-268.

Ohlemiller KK, Gagnon PM (2004) Apical-to-basal gradients in age-related cochlear degeneration and their relationship to "primary" loss of cochlear neurons. J Comp Neurol 479:103-116.

Pennypacker KR, Kassed CA, Eidizadeh S, Saporta S, Sanberg PR, Willing AE (2001) NF- $\kappa$ B is increased in neurons surviving hippocampal injury. Exp Neurol 172:307-319.

Puel JL, D’Aldin CG, Safieddine S, Eybalin M, Pujol R (1996) Excitotoxicity and plasticity of IHC-auditory nerve contributes to both temporary and permanent threshold shift. In: Scientific basis of noise-induced hearing loss (Axelsson A, Borchgrevink H, Hamernik RP, Hellstrom PA, Henderson D, Salvi RJ, eds), pp 36-42. New York: Thieme.

Puel JL, Ruel J, D’Aldin CG, Pujol R (1998) Excitotoxicity and repair of cochlear synapses after noise-trauma induced hearing loss. NeuroReport 9:2109-2114.

Pujol R, Puel JL (1999) Excitotoxicity, synaptic repair, and functional recovery in the mammalian cochlea: a review of recent findings. Ann NY Acad Sci 884:249-254.

Pujol R, Lenoir M, Robertson D, Eybalin M, Johnstone BM (1985) Kainic acid selectively alters auditory dendrites connected with cochlear inner hair cells. Hear Res 18:145-151.

Ramkumar V, Whitworth CA, Pingle SC, Hughes LF, Rybak LP (2004) Noise induces A1 adenosine receptor expression in the chinchilla cochlea. Hear Res 188:47-56.
Rask-Andersen H, Tylstedt S, Kinnefors A, Illing R (2000) Synapses on human spiral ganglion cells: a transmission electron microscopy and immunohistochemical study. Hear Res 141:1-11.

Rasmussen G (1953) Further observations of the efferent cochlear bundle. J Comp Neurol 99:61-74.

Rehm H, Wiedenmann B, Betz H (1986) Molecular characterization of synaptophysin, a major calcium-binding protein of the synaptic vesicle membrane. EMBO J 5:535-541.

Robertson D (1983) Functional significance of dendritic swelling after loud sounds in the guinea pig cochlea. Hear Res 9:263-278.

Sage C, Venteo S, Jeromin A, Roder J, Dechesne CJ (2000) Distribution of frequenin in the mouse inner ear during development, comparison with other calcium-binding proteins and synaptophysin. Hear Res 150:70-82.

Sha WC, Liou H, Tuomanen EI, Baltimore D (1995) Targeted disruption of the p50 subunit of NF- $\kappa \mathrm{B}$ leads to multifocal defects in immune responses. Cell 80:321-330.

Slepecky NB, Ulfendahl M (1993) Evidence for calcium-binding proteins and calcium-dependent regulatory proteins in sensory cells of the organ of Corti. Hear Res 70:73-84.

Sobkowicz HM, August BK, Slapnick SM (2004) Synaptic arrangements between inner hair cells and tunnel fibers in the mouse cochlea. Synapse 52:299-315.

Spicer SS, Lang H, Schulte BA, Schmiedt RA (2002) Ultrastructural changes in gerbil inner ear following ouabain application to the round window. Assoc Res Otolaryngol Abstr 25:530.

Spoendlin H (1969) Innervation patterns in the organ of Corti of the cat. Acta Otolaryngol 67:239-254.

Spoendlin H (1971) Primary structural changes in the organ of Corti after acoustic overstimulation. Acta Otolaryngol 71:166-176.

Spongr VP, Flood DG, Frisina RD, Salvi RJ (1997) Quantitative measures of hair cell loss in CBA and C57BL/6 mice throughout their life spans. J Acoust Soc Am 101:3546-3553.

Stankovic K, Rio C, Xia A, Sugawara M, Adams JC, Liberman MC, Corfas G (2004) Survival of adult spiral ganglion neurons requires erbB receptor signaling in the inner ear. J Neurosci 24:8651-8661.

Sugawara M, Corfas G, Liberman MC (2005) Influence of supporting cells on neuronal degeneration after hair cell loss. J Assoc Res Otolaryngol 6:136-147.

Wang Y, Hirose K, Liberman MC (2002) Dynamics of noise-induced cellular injury and repair in the mouse cochlea. J Assoc Res Otolaryngol 3:248-268.

White JA, Burgess BJ, Hall RD, Nadol JB (2000) Pattern of degeneration of the spiral ganglion cell and its processes in the C57BL/6J mouse. Hear Res 141:12-18.

Willott JF (1986) Effects of aging, hearing loss, and anatomical location on thresholds of inferior colliculus neurons in C57BL/6J and CBA mice. J Neurophysiol 56:391-408.

Wu W, Xie D (2002) Lipopolysaccharide enhances DNA binding activity of nuclear factor $-\kappa \mathrm{B}$ in the mouse cochlea. Zhonghua Er Bi Yan Hou Ke Za Zhi 37:19-22.

Yu Z, Zhou D, Bruce-Keller AJ, Kindy MS, Mattson MP (1999) Lack of the p50 subunit of nuclear factor- $\kappa$ B increase the vulnerability of hippocampal neurons to excitotoxic injury. J Neurosci 19:8856-8865.

Yu Z, Zhou D, Cheng G, Mattson MP (2000) Neuroprotective role for the p50 subunit of NF- $\kappa$ B in an experimental model of Huntington's disease. J Mol Neurosci 15:31-44.

Zha X-M, Bishop JF, Hansen MR, Victoria L, Abbas PJ, Mouradian MM, SH Green (2001) BDNF synthesis in spiral ganglion neurons is constitutive and CREB-dependent. Hear Res 156:53-68.

Zheng QY, Johnson KR, Erway LC (1999) Assessment of hearing in 80 inbred strains of mice by ABR threshold analyses. Hear Res 130:94-107.

Zheng X, Henderson D, Hu B, McFadden SL (1997) Recovery of structure and function of inner ear afferent synapses following kainic acid excitotoxicity. Hear Res 105:65-76.

Zheng XY, Salvi RJ, McFadden SL, Ding DL, Henderson D (1999) Recovery of kainic acid excitotoxicity in chinchilla cochlea. Ann NY Acad Sci 884: 255-269. 